\title{
Pengaruh media sosial dan konsep diri terhadap gaya hidup siswa SMAN 3 Kota Solok
}

\author{
Roza Karmila ${ }^{a .1 *,}$ Azwar Ananda b,2, Junaidi Indrawadi c,3 \\ a,b,c Program Magister Fakultas Ilmu Sosial, Universitas Negeri Padang, Padang, Indonesia \\ ${ }^{1}$ rozakarmila23@yahoo.com*; ${ }^{2}$ ananda@ fis.ac.id; ${ }^{3}$ jun_4149@yahoo.co.id \\ *korespondensi penulis
}

\begin{tabular}{ll}
\hline \multicolumn{2}{l}{ Informasi artikel } \\
\hline Sejarah artikel: & \\
Diterima & $: 01-06-2018$ \\
Revisi & $: 26-07-2018$ \\
Dipublikasikan & $: 31-10-2018$ \\
\hline
\end{tabular}

Kata kunci:

media sosial

konsep diri

gaya hidup

\begin{abstract}
ABSTRAK
Tujuan penelitian ini adalah untuk mendeskripsikan pengaruh penggunaan media sosial dan konsep diri terhadap gaya hidup siswa konsumtif SMA Negeri 3 Kota Solok. Jenis penelitian ini adalah deskriptif kuantitatif, populasi dalam penelitian ini adalah siswa SMA Negeri 3 Kota Solok yang berjumlah 1086 dan sampel penelitian ini berjumlah 181 orang. Teknik pengumpulan data menggunakan kuesioner. Teknik analisis data menggunakan uji deskripsi, uji persyaratan dan pengujian hipotesis, hasil penelitian menggambarkan bahwa media sosial berpengaruh terhadap gaya hidup konsumtif siswa SMA Negeri 3 Kota Solok dengan besaran kontribusi sebesar 14.9\%, ini berarti bahwa media sosial dapat mempengaruhi gaya hidup konsumtif siswa. Konsep Diri berpengaruh terhadap gaya hidup konsumtif. Hal ini menjelaskan bahwa dengan konsep diri yang positif dapat mempengaruhi gaya hidup siswa ke arah yang positif dan begitu juga sebaliknya. Media sosial dan konsep diri secara bersama-sama berpengaruh terhadap gaya hidup konsumtif siswa SMA Negeri 3 Kota Solok. Dengan Membekali siswa dengan ilmu pengetahuan agama dan Pendidikan Karakter, sehingga dapat memberikan pemahaman kepada siswa ke arah perilaku positif.
\end{abstract}

Keywords:

social media

self-concept

life style

\section{ABSTRACT}

The purpose of this study was to describe the effect of using social media and self-concept on the lifestyle of consumptive students of Solok 3 Senior High School. This type of research is descriptive quantitative, the population in this study were students of Solok City 3 High School, amounting to 1086 and 181 research samples. The technique of collecting data was using a questionnaire. The data analysis techniques were decryption test, requirements test and hypothesis testing. The results of the study illustrate that social media has an effect on the consumptive lifestyle of Solok 3 Senior High School students with a contribution of $14.9 \%$, this means that social media can influence the student's consumptive lifestyle. The Self Concept influences the consumptive lifestyle. This explains that with a positive self-concept can affect the lifestyle of students in a positive direction and vice versa. Social media and self-concept together influence the consumptive lifestyle of Solok 3 Senior High School students. By equipping students with religious science and character education, so as to provide students with an understanding of positive behavior.

\section{Copyright $\odot 2018$ (Roza Karmila, dkk)}

\section{Pendahuluan}

Globalisasi merupakan proses penyebaran unsur-unsur baru baik berupa informasi, pemikiran, teknologi, maupun gaya hidup secara mendunia. Sehingga dari proses tersebut, batas- batas negara menjadi sempit karena kemudahan interaksi antara negara. Teknologi Informasi di era globalisasi sangat berkembang pesat di dalam kehidupan masyarakat. Penggunaan fasilitas komunikasi yang semakin canggih memberikan 
peluang bagi setiap individu untuk mengakses informasi sesuai keinginan serta dapat berkomunikasi dengan mudah tanpa memikirkan waktu.

Saling ketergantungan ekonomi, semakin pentingnya organisasi politik dan ekonomi internasional, serta peningkatan imigrasi dan migrasi yang cepat merupakan kekuatan utama globalisasi. (Barbules \& Torres, 2000; Castle, 2004; Heater, 2000; Morais \& Ogden, 2011; Oxfam, 2006).

Gaya hidup yang berorientasi pada budaya barat merupakan gaya hidup yang dijadikan pedoman kebanyakan remaja. Gaya hidup berhubungan dengan cara kita melakukan, memiliki, menggunakan dan menampilkan perilaku (Røpke, 2009), terkait erat dengan konsumsi dan mendorong tingkat dan pola konsumsi (Backhaus, Breukers, Paukovic, Mourik, \& Mont, 2011). Pada tataran normal, gaya hidup berubah perlahan, namun globalisasi memengaruhi perubahan itu secara cepat terutama pada kelas menengah akibat dari media dan informasi yang terbuka (Zhang, Deng, Majumdar, \& Zheng, 2009).

Riset dari Asosiasi Pengguna Jasa Internet Indonesia (APJJI)(2017) mengungkapkan penggunaan internet berdasarkan usia masyarakat di Indonesia, pada rentang usia 13-34 tahun sebanyak 66,2 persen. Sementara itu, layanan yang diakses terbesar adalah chatting sebanyak 89,35 persen dari responden menggunakan chatting ketika berada di dunia maya, dan sekitar 87,13 persen juga mengakses media sosial.

Berdasarkan hasil observasi yang dilakukan pada Maret 2017, pengamatan awal berkaitan dengan gaya hidup remaja atau siswa di sekolah, terutama terlihat bahwa kebanyakan siswa sudah menggunakan telepon pintar yang nilai barangnya relatif mahal, terkadang selalu berganti-ganti, jika dilihat dari peraturan sekolah siswa dilarang menggunakan telepon pintar di dalam proses pembelajaran, namun ini hal yang sangat sulit bagi sekolah untuk menerapkan peraturan ini, data yang berkaitan dengan kasus atau siswa yang melanggar peraturan sekolah dapat dilihat pada tabel di bawah ini:

\begin{tabular}{clcl}
\multicolumn{3}{c}{ Tabel Data Siswa yang Melakukan Pelanggaran } \\
\hline No & $\begin{array}{l}\text { Jenis } \\
\text { Pelanggaran }\end{array}$ & $\begin{array}{c}\text { Jumlah } \\
\text { Siswa }\end{array}$ & Sanksi \\
\hline 1 & $\begin{array}{l}\text { Penggunaan } \\
\text { Smarphone di } \\
\text { Jam Pelajaran }\end{array}$ & 33 & $\begin{array}{l}\text { Diproses, HP } \\
\text { disita }\end{array}$ \\
2 & $\begin{array}{l}\text { Pelanggaran } \\
\text { cara berpakaian } \\
\text { dandanan yang } \\
\text { berlebihan }\end{array}$ & 18 & $\begin{array}{l}\text { Panggilan } \\
\text { orangtua }\end{array}$ \\
3 & $\begin{array}{l}\text { Pelanggaran } \\
\text { diluar batas } \\
\text { Main di } \\
\text { warnet/warung } \\
\text { pada jam PBM } \\
\text { Video/Foto } \\
\text { Porno }\end{array}$ & 10 & $\begin{array}{l}\text { Panggilan } \\
\text { orangtua,Pindah } \\
\text { Panggilan } \\
\text { orangtua,Skor }\end{array}$ \\
& 17 & $\begin{array}{l}\text { Diproses, HP di } \\
\text { sita sampai } \\
\text { tamat }\end{array}$ \\
\hline
\end{tabular}

Sumber: Wakil Kesiswaan dan BK, 2017

Kehidupan yang terlihat di media sosial yang kerap menampilkan hidup mewah dan cara instan telah menjadi "tren baru" bagi remaja/siswa. Siapa pun yang terpengaruh dengan gaya hidup media sosial itu akan mendapat stigma "tidak gaul”. Sebuah stigma yang amat memalukan bagi mereka, karena itu sedapat mungkin harus dihindari. Kebutuhan hidup yang tercipta akibat keinginan mengejar kenikmatan duniawi, berpadu dengan budaya instan, menyebabkan para remaja seringkali menjerumuskan diri ke dalam perilaku sesat. Keinginan untuk memenuhi barang-barang mewah mungkin bukan terlalu menjadi masalah bagi anak-anak orang kaya. Orang tua sanggup memenuhi sebagian besar keinginan mereka. Tapi, bagaimana dengan remaja dari keluarga paspasan? Ketika keinginan memiliki handphone, sementara anggaran dari orang tua tidak ada, maka remaja dari keluarga kurang mampu biasanya mengambil jalan pintas.

Selain itu, permasalahan yang terlihat saat ini di sekolah siswa akan dianggap mengikuti perkembangan zaman apabila telah membeli dan memakai barang-barang dengan merek terkenal, bukan lagi melalui prestasi. Sebagian siswa lain yang berada dalam tingkat ekonomi menengah juga mengikuti gaya hidup konsumtif akibat tuntutan pergaulan. Sehingga sebagian siswa kini hanya mementingkan penampilan, gengsi, dan mengikuti lingkungan sekitar. Uang saku siswa lebih dipentingkan untuk membeli 
sesuatu yang menjadi keinginan mereka dibanding dengan membeli perlengkapan sekolah yang lebih penting sebagai pendukung aktivitas sekolah. Terkait dengan gaya hidup siswa sebagai pelaku ekonomi hal yang tepat adalah mengutamakan kebutuhan yang prioritas bukan pada eksistensi di lingkungan sekolah selain itu faktor media sosial dapat mempengaruhi gaya hidup remaja.

\section{Metode}

Penelitian ini menggunakan pendekatan kuantitatif. Data penelitian dianalisis secara deskriptif dan korelasional. Analisis deskriptif dimaksudkan untuk mengambarkan kondisi variabel sebagaimana adanya tanpa memberikan perlakuan dan menarik generalisasi dari sampel terhadap populasi. Teknik inferensial digunakan untuk mengungkapkan kontribusi variabel bebas (independen variabel) terhadap variabel terikat (independent variabel). Penelitian ini akan dilaksanakan di SMAN 3 Kota Solok, alasan pemilihan lokasi penelitian ini adalah permasalahan yang ada berkaitan dengan gaya hidup siswa banyak terjadi SMAN 3 ini, ini yang menjadi dasar bagi penulis dalam penetapan lokasi penelitian. Dari populasi sebanyak 1086 siswa diambil sebagai sampel sebanyak 181 orang yang diambil secara acak.

Teknik analisis data pada tahap awal yaitu: Analisis ini digunakan untuk mengetahui pengaruh media sosial (X1), konsep diri (X2), gaya hidup (Y). Adapun rumus regresi linear berganda yang dipakai adalah sebagai berikut diolah melalui SPSS Versi 20, uji normalitas, pemeriksaan homogenitas populasi, uji multikolinearitas, uji regresi berganda regresi berganda simultan atau standar adalah kembangan lebih lanjut dari penelitian korelasional. Melalui uji regresi hendak dilihat bagaimana suatu variabel mempengaruhi variabel lain. Regresi berganda simultan atau standar juga kerap disebut standard multiple regression atau simultaneous multiple regression. Uji t Uji t dapat digunakan untuk menguji apakah masing-masing koefisien jalur mempunyai pengaruh yang signifikan/tidak. Statistik $t$ dihitung dan Uji F Uji F digunakan untuk mengetahui pengaruh variabel penyebab terhadap variabel akibat segera bersama sama yang dilakukan dengan program SPSS versi 20.

\section{Hasil dan Pembahasan}

Hasil penelitian secara deskripsi mengambarkan bahwa indikator media sosial SMA Negeri 3 Solok Termasuk kategori cukup, hasil penyebaran kuesioner mengambarkan bahwa media sosial pada umumnya siswa menggunakan dan paling dominan Facebook, Instagram, dan WhatsApp, konsep diri siswa dari analisis yang dilakukan termasuk kategori cukup dan gaya hidup siswa termasuk kategori gaya hidup konsumtif, artinya siswa selalu membeli produk-produk dari iklan yang ada di media sosial, sehingga gaya hidup konsumtif yang lebih dominan.

Pengujian persyaratan yang dilakukan bahwa media sosial, konsep diri dan gaya hidup termasuk kategori normal, karena nilai sig> 0.05. hasil pengujian homogenitas dari ketiga indikator media sosial, konsep diri dan gaya hidup termasuk kategori homogen. Hasil pengujian hipotesis mengambarkan bahwa media sosial berpengaruh terhadap gaya hidup konsumtif siswa, karena nilai thitung $>\mathrm{t}$ tabel atau nilai $\operatorname{sig}<0.005$. Pengaruh media sosial sebagai alat (online tool) memberikan peluang baru bagi warga negara muda/siswa dan kelompok pemangku kepentingan untuk menginformasikan, mengidentifikasi kepentingan bersama, mengekspresikan dan berbagi pendapat dan tuntutan, mengatur, dan mengoordinasikan intervensi-intervensi ekonomi, sosial dan politik (Hoffmann \& Lutz, 2015). Media sosial memberikan pengaruh terhadap perilaku konsumen dalam memilih produk yang dibeli, termasuk keputusan konsumsi barang-barang untuk kebutuhan gaya hidup. Di dalam kajian kewarganegaraan, remaja pada masa sekolah menengah ini disebut sebagai warga negara digital mereka yang menggunakan Internet secara teratur dan efektif setiap hari (Mossberger, Tolbert, \& McNeal, 2008).

Pengaruh pada pola konsumsi untuk gaya hidup dapat dijelaskan dari efek media sosial. Sebagaimana penelitian Zeital-Bank \& Tat, 
media sosial berefek pada otak manusia dan konsekuensinya pada kualitas hidup, pada emosi yang memainkan peran pada komunikasi manusia, sehingga untuk menghindari ancaman dari media sosial maka diperlukan interaksi yang masuk akal (2014). Oleh karena itu, remaja sebagai warga negara muda memerlukan edukasi mengenai literasi kewarganegaraan digital. Kewarganegaraan digital dapat didefinisikan sebagai normanorma perilaku dengan memperhatikan untuk penggunaan teknologi. Lebih singkat dikatakan bahwa kewarganegaraan digital sebagai kemampuan untuk berpartisipasi dalam masyarakat online (Mossberger et al., 2008). Kewarganegaraan digital juga diartikan kemampuan untuk menggunakan teknologi secara kompeten; menafsirkan dan memahami konten digital dan menilai kredibilitasnya; membuat, meneliti, dan berkomunikasi dengan alat yang tepat; berpikir kritis tentang peluang dan tantangan etika dunia digital; membuat pilihan online yang aman, bertanggung jawab, dan penuh hormat (Isman \& Gunggoren, 2014). Oleh karena itu, kewarganegaraan digital mensyaratkan adanya pengetahuan dan keterampilan untuk menggunakan teknologi secara tepat dalam dunia digital, mengelola risiko dan memanfaatkan peluang partisipatif yang ditawarkannya (Partnership for 21st Century Skills, 2014)

Hipotesis kedua konsep diri berpengaruh terhadap gaya hidup siswa, hasil yang diperoleh bahwa konsep diri berpengaruh terhadap gaya hidup siswa karena nilai $t$ hitung $>\mathrm{t}$ tabel atau nilai sig $<0.05$, hasil ini membuktikan bahwa konsep diri siswa dapat mempengaruhi gaya hidup konsumtif. Hipotesis selanjutnya mengambarkan bahwa media sosial dan konsep diri secara bersamasama berpengaruh terhadap gaya hidup siswa SMA Negeri 3 Solok, artinya media sosial dan konsep diri yang kurang baik dapat mempengaruhi gaya hidup konsumtif siswa. Remaja sebagai masa peralihan dari anakanak menuju dewasa mengalami perubahan. Menurut Steinberg (1996) selama masa remaja, perubahan penting terjadi pada cara individu berpikir dan bertindak diri mereka sendiri dalam konsep diri mereka. Sebagai individu, remaja telah dianggap dewasa secara intelektual dan mengalami berbagai perubahan kognitif ketika mereka datang untuk hamil dengan cara yang lebih canggih dan berbeda. Konsep diri bukanlah bawaan tetapi dikembangkan oleh individu melalui interaksi dengan lingkungan dan merefleksikan interaksi tersebut. Aspek konsep-diri ini penting karena menunjukkan bahwa itu dapat dimodifikasi atau diubah. Konsep diri bukanlah bawaan tetapi dikembangkan atau dikonstruksi oleh individu melalui interaksi dengan lingkungan dan merefleksikan interaksi tersebut (Bharathi \& Sreedevi, 2016). Gaya hidup dipengaruhi juga oleh self-esteem (harga diri). Self-esteem merupakan evaluasi diri atau tanggapan afeksi terhadap diri. Evaluasi tersebut mengacu persepsi seseorang tentang siapa seseorang atau konsep diri seseorang (Cast \& Burke, 2002). Kata-kata terkait seperti kepercayaan diri, harga diri, citra diri, dan harga diri positif dapat digunakan secara bergantian; bahkan konsep diri telah digunakan dalam beberapa penelitian untuk menyarankan keyakinan positif tentang diri. Dengan demikian, harapan atas penghargaan orang lain menyebabkan semakin tinggi gaya hidup yang ingin diperlihatkan. Lingkungan sekitar ikut menentukan perubahan gaya hidup ini. Ketika seseorang hidup di lingkungan dengan kohesi sosial yang tinggi memungkinkan gaya hidup yang biasa saja.

Fenomena perubahan gaya hidup merambah di kalangan remaja seperti menginginkan agar gaya berpenampilan, gaya tingkah laku, dan cara bersikap akan menarik perhatian orang lain, terutama kelompok teman sebaya. Hal tersebut terjadi karena remaja ingin diakui oleh lingkungan sekitar. Gaya hidup hedonis merupakan wujud dari ekspresi atau perilaku yang dimiliki oleh remaja untuk mencoba suatu hal yang baru. Eksistensi remaja saat ini dapat diwujudkan dengan memakai pakaian serta aksesoris bermerek, mengunjungi mall, maupun menggunakan telepon genggam dengan layanan fasilitas terbaru. Tugas perkembangan pada fase remaja antara lain mampu membina hubungan sosial yang baik dengan teman sebaya, mencapai perilaku 
sosial yang bertanggung jawab, serta mampu bersikap mandiri atas apa yang diperbuat.

Gaya hidup (lifestyle) berbeda dengan cara hidup (way of life). Cara hidup ditampilkan dengan ciri-ciri seperti norma, ritual, pola-pola tatanan sosial, dan mungkin juga cara seseorang berbahasa. Sedangkan gaya hidup bisa diekspresikan melalui apa yang dikenakan seseorang, apa yang mereka konsumsi, dan bagaimana cara mereka bersikap atau berperilaku ketika di hadapan orang lain. Gaya hidup mengandung pengertian sebagai cara hidup mencakup sekumpulan kebiasaan, pandangan dan polapola respons terhadap hidup, serta terutama perlengkapan hidup (Suyanto, 2014). Gaya hidup merupakan pola-pola tindakan yang membedakan antara satu orang dengan orang lain, yang berfungsi dalam interaksi dengan cara-cara yang mungkin tidak dapat dipahami oleh yang tidak hidup dalam masyarakat modern. Pada perkembangannya, gaya hidup saat ini tidak lagi merupakan persoalan di kalangan tertentu.

\section{Simpulan}

Penggunaan media sosial termasuk kategori cukup dan konsep diri termasuk kategori cukup, pengujian statistik secara parsial penggunaan media sosial berpengaruh terhadap gaya belajar siswa, konsep diri berkontribusi terhadap gaya hidup siswa, sedangkan secara simultan bahwa media sosial dan konsep diri secara bersama-sama terhadap gaya hidup siswa SMA Negeri 3 Solok.

\section{Referensi}

Asosiasi Penyelenggara Jasa Internet Indonesia. (2017). Infografis: penetrasi dan perilaku pengguna internet Indonesia. Jakarta.

Backhaus, J., Breukers, S., Paukovic, M., Mourik, R., \& Mont, O. (2011). Sustainable lifestyles: Today's facts \& tomorrow's trends. Wuppertal. Germany.

Barbules, N. C., \& Torres, C. A. (2000). Globalization and education: An introduction. In N. C. Barbules \& C. A.
Torres (Ed.), Globalization and Education: Critical Perspectives (hal. 127). New York, NY: Routledge.

Bharathi, T. A., \& Sreedevi, P. (2016). A study on the self-concept of adolescents. International Journal of Science and Research (IJSR), 5(10), 512-516.

Cast, A. D., \& Burke, P. J. (2002). A theory of self-esteem. Social Forces, 80(3), 10411068.

https://doi.org/10.1353/sof.2002.0003

Castle, S. (2004). Migration, citizenship, and education. In J. A. Banks (Ed.), Diversity and citizenship education: Global perspectives. San Francisco, CA: JosseyBass.

Heater, D. (2000). Does cosmopolitan thinking have a future? Review of International Studies, 26(5), 79-197. https://doi.org/10.1017/S026021050000 1790

Hoffmann, C. P., \& Lutz, C. (2015). The impact of online media on stakeholder engagement and the governance of corporations. Journal of Public Affairs, $15(2)$, 163-174. https://doi.org/10.1002/pa.1535

Isman, A., \& Gunggoren, O. C. (2014). Digital citizenship. TOJET: The Turkish Onlline Journal od Education Technology, 13(1), 73-77.

Morais, D. B., \& Ogden, A. C. (2011). Initial development and validation of the global citizenship scale. Journal of Studies in International Education, 15(5), 445466.

https://doi.org/10.1177/1028315310375 308

Mossberger, K., Tolbert, C. J., \& McNeal, R. S. (2008). Digital citizenship. The internet, society, and participation. Cambridge, Massachusetts London, England: The MIT Press.

Oxfam. (2006). Education for global citizenship: A guide for schools. Oxfam GB.

Partnership for 21st Century Skills. (2014). Reimagining citizenship for the 21st 
century: a call to action for policymakers and educators. Diambil dari http://www.p21.org/storage/documents/ Reimagining_Citizenship_for_21st_Cen tury_webversion.pdf

Røpke, I. (2009). The role of consumption in global warming-an ecological economic perspective. Anthology on global warming. Routledge.

Steinberg, L. (1996). Adolesence. New York: McGraw Hill, Inc.

Suyanto, B. (2014). Sosiologi ekonomi. Jakarta: Prenada Media.

Zeital-Bank, N., \& Tat, U. (2014). Social media and its effect on individuals and social systems. In Management, Knowledge, and Learning International Conference (hal. 1183-1190). PortorozSlovenia.

Zhang, Y., Deng, J., Majumdar, S., \& Zheng, B. (2009). Globalization of lifestyle: Golfing in China. In H. Lange \& L. Meier (Ed.), The new middle classes: Globalizing lifestyles, consumerism and environmental concern (hal. 143-158). London and New York: Springer. https://doi.org/10.1007/978-1-40209938-0 